\title{
Chapter 18 \\ Shea Butter: A Pro-Poor, Pro-Female Route to Increased Income
}

\author{
James Hammond, Mark van Wijk, Tim Pagella, Pietro Carpena, \\ Tom Skirrow, and Victoria Dauncey
}

\subsection{Introduction}

People suffering extreme poverty are typically the most vulnerable to system shocks, including those caused by climate change (FAO 2016). Finding climatesmart interventions that help the most vulnerable people is difficult because those people are typically less educated, have fewer resources to draw upon, and are less able to tolerate risk and adopt new practices (Ahmed et al. 2007).

This chapter examines marginal smallholder farmers in the Sahel, in Eastern Province, Northern Ghana, to explore whether shea butter production might offer a climate-smart solution to help the most vulnerable. Shea trees are highly abundant across the Sahel region. While the tree is culturally familiar and valued across the dry lands of West Africa (Carpena et al. 2016) it has yet to be domesticated (Hall et al. 1996). The fruits of the shea trees can be eaten, and the sun-dried kernels can be boiled down to produce a vegetable fat known as shea butter, which is used in both the food and cosmetics industries. The processing of the shea nut is laborious and considered to be a lowly form of work, which means it is often undertaken by women (who tend to be more vulnerable than men) and by poorer households. Shea butter has been widely promoted as a rural development intervention, as it is a freely accessible resource with a clear and reliable market value (Elias and Carney 2007; Hatskevich et al. 2011; Pouliot and Elias 2013). The trees also serve as a defence

\footnotetext{
J. Hammond $(\bowtie) \cdot$ T. Pagella

World Agroforestry Centre (ICRAF), Nairobi, Kenya

School of Environment, Natural Resources and Geography, Bangor University, Bangor, UK

e-mail: J.Hammond@ @ cgiar.org

M. van Wijk

International Livestock research Institute (ILRI), Nairobi, Kenya

P. Carpena $\cdot$ T. Skirrow $\cdot$ V. Dauncey

TREE AID, Bristol, UK
} 
against encroaching desertification, and preserving them helps in both the mitigation and adaptation to climate change (Mbow et al. 2014).

Shea butter production could be considered outside the definition of climatesmart agriculture (CSA) - after all, it involves the gathering of products from noncultivated trees and therefore strictly speaking does not qualify as agriculture. From a broader perspective, however, shea nut production supports the objectives of CSA, the three pillars of which are widely defined as increasing food security, increasing adaptive capacity, and mitigation of greenhouse gas emissions (FAO 2013; Neufeldt et al. 2013; Campbell et al. 2014; Lipper et al. 2014). Shea production has a positive impact on adaptive capacity: by enhancing the economic value of shea trees, it encourages the retention of trees in the landscape which will continue to provide buffering ecosystem services, promoting water and soil retention and guarding against desertification (Sinare et al. 2016). A healthy shea nut industry therefore promotes landscape-scale adaptation to climate change. The industry appears to have a neutral impact on greenhouse gas emissions, and a positive impact on food security, as is detailed below. We argue that increased shea butter production, supported by better business infrastructure leads to increased incomes and makes households more resilient to negative shocks.

The non-governmental organization (NGO) TREE AID led a 5-year programme ${ }^{1}$ (2012-2017) with several goals: (i) increase income of communities involved in sourcing and processing shea nuts through improvements in product quality and quantity; (ii) increase women's empowerment by building organizational capacity and commercial infrastructure including business groups, warehouses and credit schemes; (iii) diversify the buyers' base to allow long-term and stable incomes for the producers; (iv) protect ecosystems and promote climate resilience through the reduction of the environmental impact of shea nut sourcing and production. TREE AID's efforts included helping producers form "union" organisations focused on regional marketing, services and value addition. It worked to build buffers against market fluctuations by securing minimum price guarantees from national and international buyers of shea butter. TREE AID also provided training on improved methods for shea butter processing, including the use of hand tools and electric machinery. For this study, we evaluated the TREE AID programme using the Rural Household Multi-Indicator Survey (RHoMIS), a carefully designed, low-cost, flexible household survey tool for efficient characterisation of farm systems in communities suffering from poverty and food insecurity (Hammond et al. 2017; Rosenstock et al. 2017). This study used RHoMIS to test whether the TREE AID shea butter programme helped increase the resilience of the extremely poor in Northern Ghana.

\footnotetext{
${ }^{1}$ This project was implemented with funding from Comic Relief.
} 


\subsection{Methods}

This study focused on a population in the Upper East and Upper West regions of Northern Ghana, in the Lambussie Karni, Kassena Nankana East and Kassena Nankana West districts. Interviews with 223 households were conducted in March 2017. Informants were selected randomly from 26 villages within the project area, where informants were either project beneficiaries (101 households) or members of a control group (122 households) of non-beneficiaries. The villages were selected on the basis of their already established relationships with partner organisations. Beneficiaries in the project were self-selecting, and so it can be assumed they had more interest in shea compared to the general population. The control group, comprising households identified as future project beneficiaries, were chosen because they are directly comparable to the beneficiary households.

The RHoMIS tool uses a modular, rapid (40-60 min) digital survey to derive standardised indicators on agricultural practices, livelihoods, food security and dietary diversity, as well as gender roles (Hammond et al. 2017). A survey module was developed to collect information on use of non-timber forest products (NTFPs) and woody environmental resources. The indicator used was food availability (Frelat et al. 2016), which converts all household income and agricultural produce into a calorie per person score. Food availability was chosen in preference to cash incomes as it also takes account of self-produced and consumed items and thus provides a more comprehensive perspective on the livelihoods of the very poor (Ritzema et al. 2017). Other rapid and well-tested indicators were also gathered: experience of hunger, quantified using the Household Food Insecurity of Access Scale (HFIAS) (Coates et al. 2007); dietary diversity, assessed using the Household Dietary Diversity Score method (Swindale and Bilinsky 2006); and food groups, gathered using the Minimum Dietary Diversity for Women guide (MDD-W) (FAO and FHI 360 2016). The Progress out of Poverty Indicator (PPI) was used to crosscheck the household income figures gathered from direct questioning (IPA 2015). The use of these standard indicators allows evaluation of the project impacts in a wider frame of reference, comparison to other locations, and evaluation of changes over time should a further RHoMIS study be done at a later date.

Households were classified into three poverty classes based on their food availability scores. Households with access to less than $2500 \mathrm{kcal}$ per male adult equivalent (MAE) person per day were classed as "below the calorie line." Households above the calorie line but with a total value of activities (i.e., actual cash income plus the value of consumed agricultural produce) below US\$1.90 were classed as "below the poverty line." Households with total value of activities above US\$1.90 were classed as "above the poverty line." Welfare indicators have been presented as medians per household group, and incomes have been presented as trimmed means, where $5 \%$ of the observations at either extreme of the scale were dropped to reduce the effect of outliers. The Kruskal-Wallis test for significance was used when comparing between beneficiary and non-beneficiary households within paired poverty classes, and unless otherwise stated all significance was attributed at the 0.95 level. 


\subsection{Results}

\subsubsection{Household Livelihoods and Farm Characteristics}

The majority of the population was very poor and suffered from food insecurity. The median income per person per day was $\$ 0.09$, or $\$ 144$ per household per year. The PPI predicted that $51 \%$ of households were below the $\$ 1.90$ poverty line, although from reported household income we calculated that $99 \%$ of households were below that poverty line. Median household population was eight persons, and median land owned was 2 ha per household, with 1.6 ha cultivated in the last year. Crops sales accounted for the majority of household income ( $\$ 96$ per year), followed by environmental resources, including woody resources and non-timber forest products (\$33 per year). Livestock sales and off-farm income were low, returning median values of zero, although some households did derive income from these sources. Livestock animals were, however, widely kept, with $80 \%$ of the population keeping some form of livestock. The main crops grown were ground nut ( $85 \%$ of households), maize $(82 \%)$, millet $(58 \%)$, rice $(53 \%)$ and sorghum $(25 \%)$. The main livestock were goats (65\%), chickens (48\%), sheep (39\%) and cattle $(28 \%)$. The NTFPs reported were shea, baobab and mango, with shea by far the most widely used. Shea was gathered by $72 \%$ of the study population, baobab by $19 \%$ and mango by $8 \%$. The environmental resources were fuelwood (65\% of the population) and charcoal $(5 \%)$.

Using the food availability indicator, we calculated that the median amount of kcal available per person (adult male equivalent) per day was 3023 ; but that $42 \%$ of the population had less than $2500 \mathrm{kcal}$ available per day. Households reported on average 3 months during which it was difficult to source enough food, with the worst period being May through August. Using the HFIAS indicator, $81 \%$ of households were categorised as severely food insecure during the lean season, $9 \%$ moderately food insecure, 3\% mildly food insecure and 7\% food secure. Dietary diversity was low during the lean season, with a median score of 3 food groups eaten at least weekly. Outside the lean season the dietary diversity score was considerably better, with a median score of 7 .

Very few households were considered above the poverty line, either among beneficiaries or non-beneficiaries (see Fig. 18.1). There were, however, more households in the poorest category (below the calorie line) among the non-beneficiary group than the beneficiaries $(p<0.05)$. The plausible reason for this, looking at the sources of calories and income illustrated in Fig. 18.1, is the major role played by NTFPs. The mean amount of income derived from NTFPs is greater amongst project beneficiaries. Amongst both beneficiaries and non-beneficiaries the importance (as a proportion of calorie provision) of NTFPs and woody resources is greater for poorer households. 

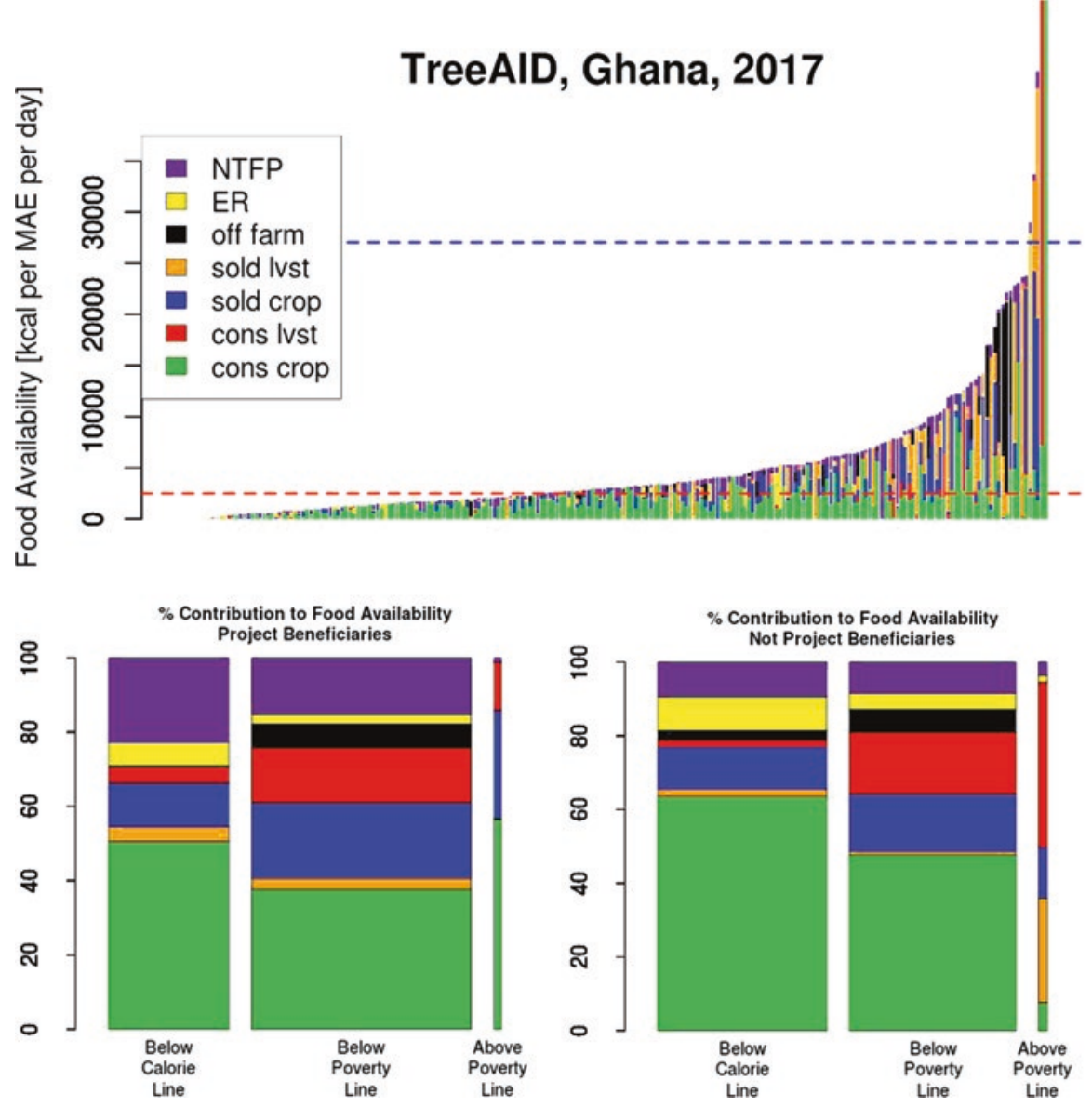

Fig. 18.1 Household livelihoods displayed as potential food availability, kcal per male adult equivalent person per day. The upper panel shows the amount of calories potentially derived from different income (or food) sources, and each column represents an individual household. The horizontal dashed lines represent thresholds used to divide the population. The red dashed line represents minimum calorie requirement per day ( $2500 \mathrm{kcal}$ per MAE), and the blue line represents the poverty line threshold of $\$ 1.90$ per person per day. The lower panel shows the mean proportion of income derived from each income source for households in three poverty classes: those below the calorie line, those below the poverty line and those above the poverty line; the width of the column represents the number of households in that category. The population is also divided into beneficiaries of the project and non-beneficiaries. The livelihood sources are represented in the legend in the upper right corner, with the following abbreviations: NTFP non-timber forest products, ER environmental resources, lvst livestock, cons consumed 
Table 18.1 Household welfare indicators, by beneficiary and non-beneficiary (control) households, and by poverty class. Food availability is shown as kilocalories per MAE; the proportion of households suffering from severe food insecurity is determined using HFIAS; the dietary diversity score is determined using the household dietary diversity score method (HDDS) and the ten food categories from the MDD-W indicator; and PPI is used to predict the likelihood of households being in poverty using the $\$ 1.90$ poverty line. All values shown are median averages, and statistical significance was established using the Kruskal-Wallis rank sum test, comparing between beneficiary and control households within the same poverty class. Differences significant at $p<0.05$ are highlighted in bold, and differences at $p<0.1$ are italicised

\begin{tabular}{|c|c|c|c|c|c|c|c|}
\hline $\begin{array}{c}\text { Project } \\
\text { beneficiary }\end{array}$ & $\begin{array}{c}\text { Poverty } \\
\text { class }\end{array}$ & $\begin{array}{c}\text { Food } \\
\text { availability } \\
\text { (kcal/MAE) }\end{array}$ & $\begin{array}{c}\text { Income } \\
\$ / \text { pers/ } \\
\text { day }\end{array}$ & $\begin{array}{c}\% \text { hh } \\
\text { severley } \\
\text { food } \\
\text { insecure }\end{array}$ & $\begin{array}{c}\text { Dietary } \\
\text { diversity } \\
\text { score (lean } \\
\text { season) }\end{array}$ & $\begin{array}{l}\text { Hungry } \\
\text { months }\end{array}$ & $\begin{array}{c}\text { PPI } \\
\text { predicted \% } \\
\text { under } \\
\text { poverty line }\end{array}$ \\
\hline Control & all & 2558 & 0.05 & 84 & 3 & 3 & 51 \\
\hline Beneficiary & all & 3885 & 0.14 & 76 & 3 & 3 & 35 \\
\hline Control & $\begin{array}{l}\text { below } \\
\text { calorie } \\
\text { line }\end{array}$ & 1307 & 0.01 & 87 & 3 & 3 & 62 \\
\hline Beneficiary & $\begin{array}{l}\text { below } \\
\text { calorie } \\
\text { line }\end{array}$ & 1277 & 0.04 & 83 & 2 & 3 & 51 \\
\hline Control & $\begin{array}{l}\text { below } \\
\text { pov line }\end{array}$ & 4756 & 0.17 & 83 & 3 & 3 & 35 \\
\hline Beneficiary & $\begin{array}{l}\text { below } \\
\text { pov line }\end{array}$ & 5548 & 0.24 & 73 & 4 & 3 & 35 \\
\hline Control & $\begin{array}{c}\text { above } \\
\text { pov line }\end{array}$ & 43795 & 1.92 & 67 & 4 & 1 & 10 \\
\hline Beneficiary & $\begin{array}{c}\text { above } \\
\text { pov line }\end{array}$ & 128014 & 1.15 & 50 & 3 & 2 & 17 \\
\hline
\end{tabular}

\subsubsection{The Impacts on Household Welfare Indicators}

When looking at the whole population, significant effects on household welfare indicators were found (see Table 18.1). Beneficiary households had higher potential calorie availability, higher cash incomes, and better progress out of poverty scores. Furthermore, the reduction in the number of households classified as severely food insecure (using the HFIAS indicator) scored a low but non-significant $p$ value of 0.12 , implying, in combination with the above-mentioned significant effects, positive project outcomes on the beneficiary population.

The poorest households, below the calorie line, showed an increase in actual cash incomes from US\$0.01 per person per day to US $\$ 0.04$ per person per day. Increase in the food availability score for beneficiary households below the poverty line was found to be significant only at the $p<0.1$ level. 


\subsubsection{Shea Derived Incomes}

Table 18.2 shows a breakdown of incomes derived from shea and firewood, as well as proportions of the populations engaged in each activity. The project achieved a statistically significant increase of income from sales of shea the whole population level. The increased income was due to sales of shea butter, and not shea nuts or fruits. Furthermore, the beneficiary population derived less income from sale of fuelwood compared to the control. The total number of households using shea was also higher in the beneficiary population $(p<0.1)$, the total number selling shea butter was higher, and the total number selling fuelwood was lower.

When considering households of different poverty classes, those below the calorie line showed the most marked changes: average income from shea butter was almost ten times higher among the beneficiary population, and more than twice the proportion of households took part in shea butter selling. A similar pattern was observed amongst the households below the poverty line, although effects were at the $\mathrm{p}<0.1$ level, perhaps reflecting the greater variation in income sources among households in that poverty class. An unexpected observation was that the beneficiary households above the poverty line showed less income and engagement with shea than non-beneficiary households, although there were so few households in that class that the finding cannot be considered robust.

\subsection{What Factors Led to the Success of This Project?}

The reasons for the beneficiaries' higher incomes from shea are multiple. The survey data shows that the quantity of shea fruit gathered per household did not significantly differ between beneficiaries and non-beneficiaries (mean $130 \mathrm{~kg} / \mathrm{year}$ ), but the amount converted into shea butter did. Beneficiary households yielded on average $37 \mathrm{~kg} /$ year of shea butter compared to $13 \mathrm{~kg} / \mathrm{year}$ for non-beneficiaries $(p<0.01)$. The high difference in average shea butter production may be in part due to the higher number of beneficiaries who produced shea butter compared to nonbeneficiaries, as well as more efficient production techniques, including access to tools and machines that reduced the drudgery of the process. Also, the ability to store shea nuts or butter may have reduced wastage. There was no significant evidence that beneficiaries sold more nuts or fruits compared to non-beneficiaries, nor was there significant evidence that the project achieved higher sale prices for shea butter for beneficiaries (median price $1.5 \$ / \mathrm{kg}$ ). It therefore appears that the project created a greater "market pull" by facilitating easier and more efficient processing, and by establishing sales groups.

The different usage of fuelwood may be an important clue as to the production of shea butter. Non-beneficiaries collected the same amount of fuelwood as beneficiaries but sold more of it as fuelwood. It may be, therefore, that beneficiaries burned the fuelwood they gathered in their production of shea butter. This is strongly implied 


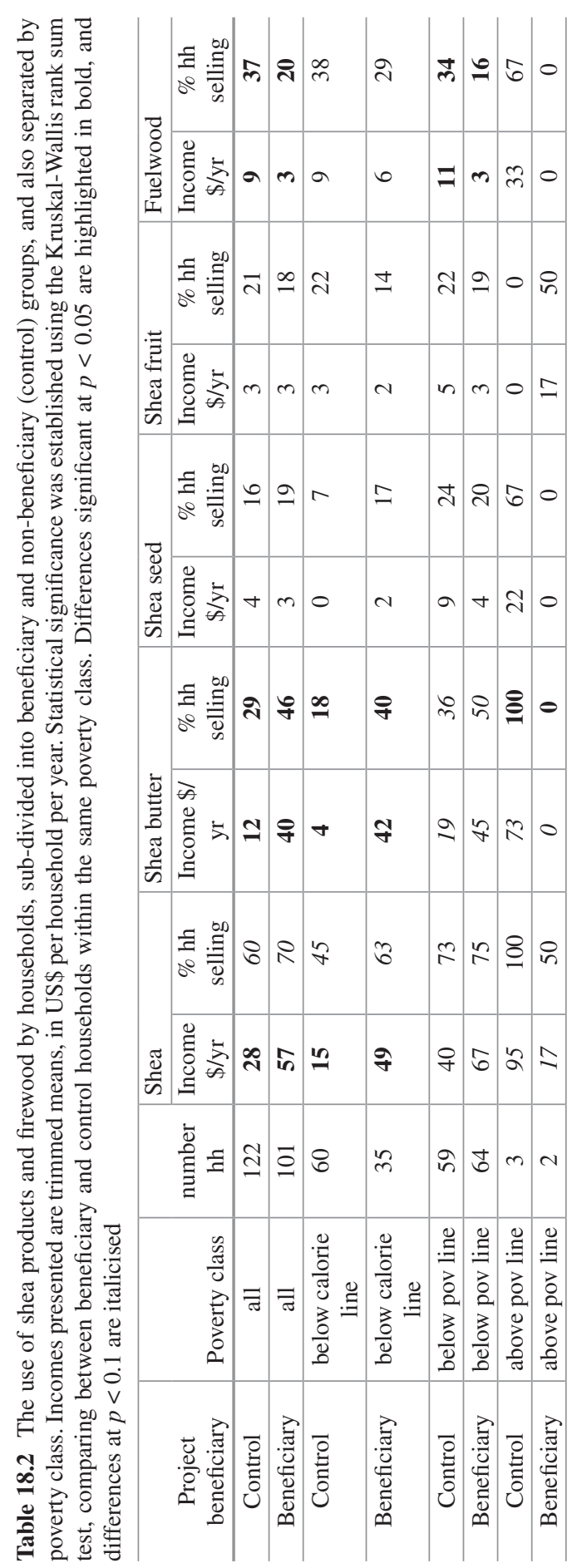




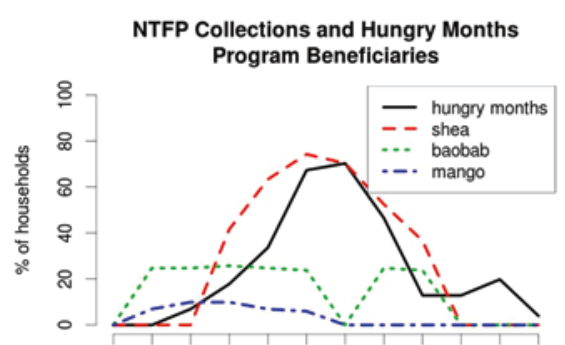

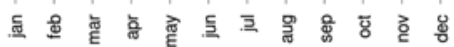

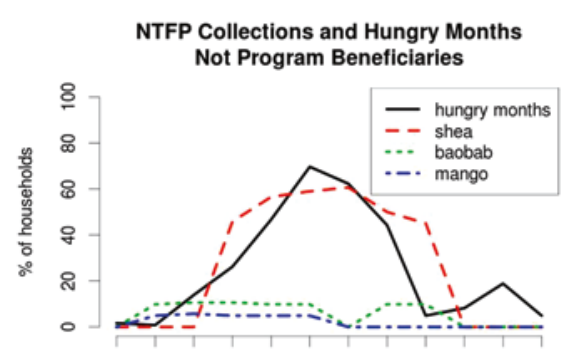

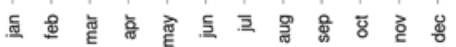

Fig. 18.2 The timings of reported "hungry months" during which food is in short supply, and of NTFP gathering. The collection of shea fruit seems to be well matched with the hungry season

from the survey data, and if true would be a clear case of adding extra value to already gathered environmental resources. It also implies that total greenhouse gas emissions were not increased through increased shea production, as non-beneficiaries gathered an equal amount of fuel wood but sold it instead of using it for shea production. Local informants believed that this fuel wood was not being sold to shea butter producers, but this was not established quantitatively. If it was in fact sold to producers, this fact could undermine our conclusion regarding emissions.

The households below the calorie line showed a much higher adoption rate of shea and shea butter sales amongst the beneficiary group compared to nonbeneficiaries. This partly reflects the fact that shea butter is highly labour intensive and does not immediately generate a large amount of income. As a result, shea does not attract wealthier families who have opportunities elsewhere. The difficulty of shea production may be a blessing as well as a curse: it does not offer an easy path out of poverty, but due to the initial low cash investment and high labour cost, it may be a commodity which is well suited to improving incomes and food security for the very poor and vulnerable.

The timing of the shea fruit season also makes it a useful crop to combat food insecurity, and may explain in part the popularity of the crop. Figure 18.2 shows the timing of lean season and NTFP harvesting, as reported by beneficiary and nonbeneficiary households. It is clear that shea harvesting coincides with the lean season, and that baobab and mango do not. Furthermore, it can be seen that the lean season starts a little later for project beneficiaries, possibly as an effect of the project interventions. The shea harvest seems to be particularly well timed to meet a local need.

Shea collection is also a strongly gendered activity, practiced mainly by women: $70 \%$ of households surveyed reported women gathering shea, with only $21 \%$ reporting men involved. Most importantly, the income is predominantly controlled by women, with $70 \%$ of households reporting female control of shea incomes and only $11 \%$ reporting male control. The gender breakdown of work and income control did not differ significantly between the beneficiary and control populations. The gendered nature of shea activities may also have helped the project gain traction in an environment where opportunities for women can be scarce and where attempts to increase the female share of household income can be a challenge (Johnson et al. 2016). 
The project's implementing staff considered the construction of the warehouses for the union organizations to store shea products to be an important part in the project. The warehouses acted as a hub for the unions, a safe and pest-free storage area, and a place to access machinery to process shea. The warehouses also may have contributed to the female control of shea income because they were not gendered spaces: homesteads can have gender taboos associated with storage areas, making it difficult for women to extract full value from shea products. Study results did include suggestions for improving the warehouses. First, they were constructed late in the project; had they been constructed earlier the unions may have been more successful in negotiating guaranteed minimum prices. Another suggested improvement was a credit system whereby union members could receive some payment when depositing shea in the warehouses, to be set against the final payment they received when selling the shea butter. Unfortunately, this system could not be established due to logistical complications.

\subsection{Implications for Development}

This project once again demonstrated the usefulness of the RHoMIS tool. It permitted evaluation of the project at low cost, and the data gathered can now be pooled with that from other sites and used to build a body of evidence on routes to achieving resilience of small holder rural households. The use of a rapid and well-designed evaluation tool permitted a deeper understanding of the project impacts on household welfare than could otherwise have been achieved.

This study reveals the benefits of shea butter value chain work. The more successful interventions were training of households in shea butter extraction techniques and the formation of unions providing access to storage and machinery. The financial infrastructure proved more challenging to organize, with credit schemes and minimum price guarantees coming either too late or not at all. Despite these challenges, we have shown that the poorer sectors of society, and particularly females, benefited from the project in terms of income and food security.

A number of factors contributed to the success of this project and consideration of these may help improve other value-chain projects relating to climate-smart objectives.

- Gender inclusive: Supporting shea chains makes it easy to reach women, as shea is already a gendered (female-biased) product and not linked to land ownership.

- Pro-poor: Due to the high labour requirements and low initial cash investments, shea butter is a commodity well-suited to improving incomes and food security for the very poor and vulnerable sections of society. It unattractive to wealthier households, which may create more opportunities for the poor.

- Culturally acceptable: Shea was already culturally well accepted, and abundant, with little risk entailed in entering the market. 
- Timely: The timing of the potential shea fruit income suited a local need: income during the lean season.

- Adoptable: The project interventions were simple and accessible to many households: hand tools, training, unions and access to storage space and machinery.

The project did reveal some challenges. The business training and value chain enhancement took longer to establish than was initially hoped, and price guarantees from buyers could not be secured. Earlier prioritisation of these activities may make them more successful in the future.

Evaluating the full environmental impact of the project was beyond the scope of the study, but there is no doubt that continued use of shea trees entails ecosystem benefits. One possible negative environmental consequence could be increased use of fuel wood for shea processing. We did not see evidence of this, but if it is found to be a problem, it could be managed by establishment of fuel lots. By preserving and encouraging the maintenance of trees in the landscape, shea production combats desertification and promotes preservation of soil and water resources. By providing both a source of food and opportunities for cash income, it contributes to healthier households and communities, making them more resilient in the face of environmental shocks. In this case, the facilitation of increased shea butter production and sales offered significant benefits to the most vulnerable smallholder farmers: decreasing the number of people in extreme poverty.

\section{References}

Ahmed A, Hill R, Smith L et al (2007) The world's most deprived: characteristics and causes of extreme poverty and hunger. International Food Policy Research Institute, Washington, DC. https://doi.org/10.2499/0896297705

Campbell B, Thornton P, Zougmoré R et al (2014) Sustainable intensification: what is its role in climate smart agriculture? Curr Opin Environ Sustain 8:39-43. https://doi.org/10.1016/j. cosust.2014.07.002

Carpena P, Kaboret B, Ouedraogo D et al (2016) Supporting the development of democratic and locally controlled small-scale enterprises based on non-timber forest products in Burkina Faso. Food Chain 6(2):77-91. https://doi.org/10.3362/2046-1887.2016.005

Coates J, Swindale A, Bilinsky P (2007) Household food insecurity access scale (HFIAS) for measurement of food access: indicator guide. Food and Nutrition Technical Assistance, Washington, DC

Elias M, Carney J (2007) African shea butter: a feminized subsidy from nature. Africa 77:37-62. https://doi.org/10.3366/afr.2007.77.1.37

FAO (2013) Climate-smart agriculture sourcebook. Available at: http://www.fao.org/docrep/018/ i3325e/i3325e00.htm

FAO (2016) State of Food and Agriculture. Rome

FAO and FHI 360 (2016) Minimum dietary diversity for women: a guide to measurement. Available at: http://www.fao.org/3/a-i5486e.pdf

Frelat R, Lopez-Ridaura S, Giller K et al (2016) Drivers of household food availability in subSaharan Africa based on big data from small farms. Proc Natl Acad Sci 113(2):458-463. https://doi.org/10.1073/pnas.1518384112 
Hall J, Aebischer D, Tomlinson H et al (1996) Vitellaria paradoxa: a monograph. School of Agricultural and Forest Sciences. University of Wales, Bangor

Hammond J, Fraval S, van Etten J et al (2017) The rural household multi-indicator survey (RHoMIS) for rapid characterisation of households to inform climate smart agriculture interventions: description and applications in East Africa and Central America. Agric Syst 151:225-233. https://doi.org/10.1016/j.agsy.2016.05.003

Hatskevich A, Jeníček V, Antwi Darkwah S (2011) Shea industry: a means of poverty reduction in northern Ghana. Agric Trop Subtrop 44(4):223-228

IPA (2015) Progress out of poverty index. Available at: http://www.progressoutofpoverty.org/

Johnson N, Kovarik C, Meinzen-Dick R et al (2016) Gender, assets, and agricultural development: lessons from eight projects. World Dev 83:295-311. https://doi.org/10.1016/j. worlddev.2016.01.009

Lipper L, Thornton P, Campbell B et al (2014) Climate-smart agriculture for food security. Nature Clim Change 4(12): 1068-1072

Mbow C, Van Noordwijk M, Luedeling E, Neufeldt H, Minang PA, Kowero G (2014) Agroforestry solutions to address food security and climate change challenges in Africa. Curr Opin Environ Sustain 6:61-67. https://doi.org/10.1016/j.cosust.2013.10.014

Neufeldt H, Jahn M, Campbell B et al (2013) Beyond climate-smart agriculture: toward safe operating spaces for global food system. Agric Food Secur 2(1):12. https://doi. org/10.1186/2048-7010-2-12

Pouliot M, Elias M (2013) To process or not to process? Factors enabling and constraining shea butter production and income in Burkina Faso. Geoforum 50(Supp C):211-220. https://doi. org/10.1016/j.geoforum.2013.09.014

Ritzema R, Frelat R, Douxchamps S et al (2017) Is production intensification likely to make farm households food-adequate? A simple food availability analysis across smallholder farming systems from East and West Africa. Food Security 9(1):115-131. https://doi.org/10.1007/ s12571-016-0638-y

Rosenstock T, Lamanna C, Chesterman S et al (2017) When less is more: innovations for tracking progress toward global targets. Curr Opin Environ Sustain 2:54-61. https://doi.org/10.1016/j. cosust.2017.02.010

Sinare H, Gordon L, Kautsky E (2016) Assessment of ecosystem services and benefits in village landscapes: a case study from Burkina Faso. Ecosyst Serv 21:141-152. https://doi. org/10.1016/j.ecoser.2016.08.004

Swindale A, Bilinsky P (2006) Household dietary diversity score (HDDS) for measurement of household food access: indicator guide. Food and Nutrition Technical Assistance Project. Academy for Educational Development, Washington, DC

Open Access This chapter is licensed under the terms of the Creative Commons Attribution 4.0 International License (http://creativecommons.org/licenses/by/4.0/), which permits use, sharing, adaptation, distribution and reproduction in any medium or format, as long as you give appropriate credit to the original author(s) and the source, provide a link to the Creative Commons license and indicate if changes were made.

The images or other third party material in this chapter are included in the chapter's Creative Commons license, unless indicated otherwise in a credit line to the material. If material is not included in the chapter's Creative Commons license and your intended use is not permitted by statutory regulation or exceeds the permitted use, you will need to obtain permission directly from the copyright holder.

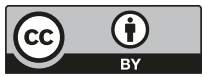

